University of Nebraska - Lincoln

DigitalCommons@University of Nebraska - Lincoln

\title{
Field-Scale Remediation of a Metolachlor-Contaminated Spill Site Using Zerovalent Iron
}

\author{
Steven Comfort \\ University of Nebraska - Lincoln, scomfort1@unl.edu \\ Patrick J. Shea \\ University of Nebraska-Lincoln and University of Nebraska Medical Center, pshea1@unl.edu \\ Thomas A. Machacek \\ University of Nebraska - Lincoln, tmachacek1@unl.edu \\ H. Gaber \\ University of Nebraska - Lincoln \\ B.-T. Oh \\ University of Nebraska - Lincoln
}

Follow this and additional works at: https://digitalcommons.unl.edu/natrespapers

Part of the Natural Resources and Conservation Commons

Comfort, Steven; Shea, Patrick J.; Machacek, Thomas A.; Gaber, H.; and Oh, B.-T., "Field-Scale Remediation of a Metolachlor-Contaminated Spill Site Using Zerovalent Iron" (2001). Papers in Natural Resources. 157. https://digitalcommons.unl.edu/natrespapers/157

This Article is brought to you for free and open access by the Natural Resources, School of at DigitalCommons@University of Nebraska - Lincoln. It has been accepted for inclusion in Papers in Natural Resources by an authorized administrator of DigitalCommons@University of Nebraska - Lincoln. 


\title{
Field-Scale Remediation of a Metolachlor-Contaminated Spill Site Using Zerovalent Iron
}

\author{
S. D. Comfort*, P. J. Shea, T. A. Machacek, H. Gaber, and B.-T. Oh
}

\begin{abstract}
Pesticide spills are common occurrences at agricultural cooperatives and farmsteads. When inadvertent spills occur, chemicals normally beneficial can become point sources of ground and surface water contamination. We report results from a field trial where approximately $765 \mathrm{~m}^{3}$ of soil from a metolachlor [2-chloro- $N$-(2-ethyl-6-methylphenyl)- $N$-(2-methoxy-1-methylethyl) acetamide] spill site was treated with zerovalent iron $\left(\mathrm{Fe}^{0}\right)$. Preliminary laboratory experiments confirmed metolachlor dechlorination by $\mathrm{Fe}^{0}$ in aqueous solution and that this process could be accelerated by adding appropriate proportions of $\mathrm{Al}_{2}\left(\mathrm{SO}_{4}\right)_{3}$ or acetic acid $\left(\mathrm{CH}_{3} \mathrm{COOH}\right)$. The field project was initiated by moving the stockpiled, contaminated soil into windrows using common earth-moving equipment. The soil was then mixed with water $\left(0.35-0.40 \mathrm{~kg} \mathrm{H}_{2} \mathrm{O} \mathrm{kg}^{-1}\right)$ and various combinations of $5 \% \mathrm{Fe}^{0}(\mathrm{w} / \mathrm{w}), 2 \%$ $\mathrm{Al}_{2}\left(\mathrm{SO}_{4}\right)_{3}(\mathrm{w} / \mathrm{w})$, and $0.5 \%$ acetic acid $(\mathrm{v} / \mathrm{w})$. Windrows were covered with clear plastic and incubated without additional mixing for $90 \mathrm{~d}$. Approximately every $14 \mathrm{~d}$, the plastic sheeting was removed for soil sampling and the surface of the windrows rewetted. Metolachlor concentrations were significantly reduced and varied among treatments. The addition of $\mathrm{Fe}^{0}$ alone decreased metolachlor concentration from 1789 to $504 \mathrm{mg} \mathrm{kg}^{-1}$ within 90 d, whereas adding $\mathrm{Fe}^{0}$ with $\mathrm{Al}_{2}\left(\mathrm{SO}_{4}\right)_{3}$ and $\mathrm{CH}_{3} \mathrm{COOH}$ decreased the concentration from 1402 to $13 \mathrm{mg} \mathrm{kg}^{-1}$. These results provide evidence that zerovalent iron can be used for on-site, field-scale treatment of pesticide-contaminated soil.
\end{abstract}

$\mathrm{P}$ ESTICIDE spills and accidents involving farm chemicals take place each year on farmsteads and cooperatives. When these events occur, normally beneficial chemicals become sources of contamination for ground and surface water. Although the soil-water environment has an enormous potential to naturally attenuate xenobiotic compounds, this capacity can be exceeded when chemicals are either deliberately or inadvertently released to localized areas. To combat these point sources of contamination, treatments are needed that can alter the chemical structure of the contaminant so that natural attenuation can proceed.

The realization that many pollutants normally considered persistent in aerobic environments may be less persistent under anaerobic conditions has generated considerable interest in engineering a reducing environment in soils, sediments, and aquifers for remediation purposes. Under reducing conditions, detoxification of many contaminants can occur through reductive dehalogenation reactions. Although there are exceptions, as when vinyl chloride, a human carcinogen, is produced from reduction of more highly chlorinated compounds (Suflita et al., 1982), there is ample evidence to indicate that reducing or removing electron-withdrawing moieties from parent structures can result in more biodegradable prod-

School of Natural Resource Sciences, University of Nebraska-Lincoln, Lincoln, NE 68583-0915. Received 1 Dec. 2000. *Corresponding author (scomfort@unl.edu).

Published in J. Environ. Qual. 30:1636-1643 (2001). ucts (Hundal et al., 1997; Singh et al., 1998a; Fathepure and Tiedje, 1999). Based on this premise, one technology gaining widespread acceptance is the use of zerovalent metals for remediating ground water contaminated with chlorinated solvents. Zerovalent iron $\left(\mathrm{Fe}^{0}, \mathrm{E}_{\mathrm{h}}^{\mathrm{o}}=\right.$ $-409 \mathrm{mV}$; Weast, 1978) is an avid electron donor and has a high capacity to reduce a wide array of organic compounds. Under aerobic conditions, oxygen is the usual electron acceptor, while in anoxic environments, electron release from the reaction of $\mathrm{Fe}^{0}$ with water can be coupled to the reduction of chlorinated and nitroaromatic compounds (Gillham and O'Hannesin, 1994; Agrawal and Tratnyek, 1996).

Current research has focused on the use of zerovalent metals for in situ treatment of contaminated ground water, with less research on using zerovalent metals for treating contaminated soils. Earlier work with zerovalent zinc demonstrated the utility of metals to treat soils contaminated with dichlorodiphenyltrichloroethane (DDT) (Staiff et al., 1977), methyl parathion (Butler et al., 1981), and polychlorinated biphenyls (Cutshall et al., 1993). More recent research indicates the tremendous potential of $\mathrm{Fe}^{0}$ to remediate soils contaminated with 2,4,6-trinitrotoluene (TNT), hexahydro-1,3,5-trinitro1,3,5-triazine (RDX) (Hundal et al., 1997; Singh et al., 1998a, 1999), and atrazine (Singh et al., 1998b). Despite encouraging results, this work has yet to evolve into routine large-scale treatment of contaminated spill sites.

Our objective was to use zerovalent iron to remediate a metolachlor-contaminated field site. We report laboratory observations demonstrating the capacity of $\mathrm{Fe}^{0}$ to dechlorinate metolachlor in aqueous solution, then demonstrate the effectiveness of $\mathrm{Fe}^{0}$ to decrease metolachlor concentrations in static soil microcosms and at the field scale in soil windrows.

\section{MATERIALS AND METHODS}

\section{Metolachlor Spill Site}

The metolachlor spill site was at a farm cooperative in southwestern Nebraska. This cooperative had been using a halfacre bentonite clay-lined lagoon to contain potentially contaminated storm runoff water and other excess wastewater. In 1995, an accidental release of metolachlor from a storage tank resulted in $2858 \mathrm{~L}$ of unrecovered product, some of which ran into the sump that drains into the lagoon. The spill resulted in approximately $765 \mathrm{~m}^{3}\left(1000 \mathrm{yd}^{3}\right)$ of contaminated soil that was excavated from the lagoon, stockpiled into two large windrows, and held for remedial treatment. The targeted contaminant was metolachlor, which was present at concentrations in excess of $1400 \mathrm{mg} \mathrm{kg}^{-1}$, but soil analysis revealed additional pesticides such as atrazine (6-chloro- $N^{2}$-ethyl- $N^{4}$-isopropyl1,3,5-triazine-2,4-diamine; initial concentration $\left.>250 \mathrm{mg} \mathrm{kg}^{-1}\right)$, alachlor [2-chloro-2',6'-diethyl- $N$-(methoxymethyl)acetanilide;

Abbreviations: HPLC, high-performance liquid chromatography. 
$\left.>90 \mathrm{mg} \mathrm{kg}^{-1}\right]$, pendimethalin [ $N$-(1-ethylpropyl)-3,4-dimethyl2,6-dinitrobenzenamine; $\left.>90 \mathrm{mg} \mathrm{kg}^{-1}\right]$, and chlorpyrifos $[O, O$ diethyl $O$-(3,5,6-trichloro-2-pyridyl) phosphorothioate; $>25 \mathrm{mg}$ $\left.\mathrm{kg}^{-1}\right]$.

\section{Laboratory Solution Experiments}

Aqueous solutions of metolachlor were prepared from the commercial product Dual 8E (Syngenta, Greensboro, NC) and spiked with $\left[{ }^{14} \mathrm{C}\right.$-U-phenyl] metolachlor $\left(28.6 \mu \mathrm{Ci} \mathrm{mg}^{-1}\right)$ to produce a final concentration of $32 \mathrm{~Bq} \mathrm{~mL}^{-1}$. Experimental units consisted of 250-mL Erlenmeyer flasks filled with $150 \mathrm{~mL}$ of metolachlor solution. All flasks were covered with Parafilmcoated stoppers and agitated on a reciprocating shaker at ambient temperature $\left(23^{\circ} \mathrm{C}\right)$.

Two sets of companion batch experiments were conducted with zerovalent iron. The first set compared the destructive capacity of $\mathrm{Fe}^{0}$ with and without $\mathrm{Al}_{2}\left(\mathrm{SO}_{4}\right)_{3}$; the second used $\mathrm{Fe}^{0}$ with and without acetic acid. Initial metolachlor concentration was $1.09 \mathrm{~m} M$ for the $\mathrm{Fe}^{0}-\mathrm{Al}_{2}\left(\mathrm{SO}_{4}\right)_{3}$ experiment and $1.00 \mathrm{~m} M$ for the $\mathrm{Fe}^{0}$-acetic acid experiment. Each treatment (including controls) was replicated three times. Each treatment flask (containing $150 \mathrm{~mL}$ of metolachlor solution) received $18.75 \mathrm{~g}$ of unannealed $\mathrm{Fe}^{0}$, with and without $0.75 \mathrm{~g}$ commercial-grade $\mathrm{Al}_{2}\left(\mathrm{SO}_{4}\right)_{3}$ or $0.75 \mathrm{~mL}$ glacial acetic acid. At $0,2,4,6,8,12$, 16,24 , and $48 \mathrm{~h}, 1.5-\mathrm{mL}$ aliquots were removed and transferred to $1.7-\mathrm{mL}$ polypropylene microcentrifuge tubes, centrifuged at $13000 \times g$ for $10 \mathrm{~min}$, and analyzed by high-performance liquid chromatography (HPLC) for metolachlor and dechlorinated metolachlor. Carbon-14 in the aqueous solution was also monitored using the same sampling scheme by mixing 1 $\mathrm{mL}$ of uncentrifuged sample with $6 \mathrm{~mL}$ of Ultima Gold cocktail (Packard, Meriden, CT) and analyzed by liquid scintillation counting (LSC) using a Packard 1900TR liquid scintillation counter (Packard Instrument Co., Downers Grove, IL). Chloride analysis was also conducted on the samples taken for HPLC analysis with a Dionex (Sunnyvale, CA) DX-120X ion chromatograph using an AS14 IonPac column and a sodium carbonate $(3.5 \mathrm{mM})$-sodium bicarbonate $(1.0 \mathrm{mM})$ eluent at

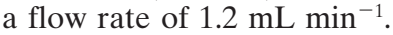

To determine differences in biodegradability between metolachlor and the $\mathrm{Fe}^{0}$-treated metolachlor products (primarily dechlorinated metolachlor), $25 \mathrm{~mL}$ of $0.35 \mathrm{~m} M$ metolachlor solution (spiked with ${ }^{14} \mathrm{C}$-metolachlor) was treated with and without $4.5 \mathrm{~g} \mathrm{Fe}^{0}$ and mixed with $24 \mathrm{~mL}$ of double strength Pseudomonas minimum media (without glucose; Hundal et al., 1997). Solutions were transferred to sterilized glass jars, then inoculated with $1 \mathrm{~mL}$ of a consortium obtained from the metolachlor-contaminated soil. This inoculum was extracted by shaking $4 \mathrm{~g}$ soil with $20 \mathrm{~mL}$ of saline solution for $48 \mathrm{~h}$. The saline solution contained $\left(\mathrm{g} \mathrm{L}^{-1}\right) \mathrm{NaCl}(8.5), \mathrm{KH}_{2} \mathrm{PO}_{4}(0.3)$, $\mathrm{Na}_{2} \mathrm{HPO}_{4}(0.6)$, and peptone (0.1). Evolved ${ }^{14} \mathrm{CO}_{2}$ was captured by placing $10 \mathrm{~mL}$ of $0.5 \mathrm{M} \mathrm{NaOH}$ in a $20-\mathrm{mL}$ scintillation vial and suspending it inside the sealed glass jar and over the inoculated media. Carbon dioxide traps were changed approximately every $5 \mathrm{~d}$. Captured ${ }^{14} \mathrm{CO}_{2}$ was determined by removing $0.5 \mathrm{~mL}$ from the $\mathrm{CO}_{2}$ traps, mixing with scintillation cocktail, and determining total ${ }^{14} \mathrm{C}$ activity by liquid scintillation counting.

\section{Laboratory Soil Incubation Experiments}

Because solution experiments provided evidence that small additions of $\mathrm{CH}_{3} \mathrm{COOH}$ or $\mathrm{Al}_{2}\left(\mathrm{SO}_{4}\right)_{3}$ facilitated $\mathrm{Fe}^{0}$-mediated destruction of metolachlor, we subsequently conducted batch studies with the metolachlor-contaminated soil to determine optimum concentrations needed for efficient metolachlor destruction in static soil microcosms. This was accomplished by incubating $20 \mathrm{~g}$ (oven dry) soil with $5 \% \mathrm{Fe}^{0}$ (w/w) in $40-\mathrm{mL}$
Teflon centrifuge tubes at $30^{\circ} \mathrm{C}$ and a soil water content of $0.40 \mathrm{~kg} \mathrm{~kg}^{-1}$. Aluminum sulfate additions were between 0 and $5 \%(\mathrm{w} / \mathrm{w})\left[0-1.0 \mathrm{~g} \mathrm{Al}_{2}\left(\mathrm{SO}_{4}\right)_{3}\right.$ to $20 \mathrm{~g}$ soil $]$. Acetic acid additions were between 0 and $2.5 \%(0-0.5 \mathrm{~mL}$ to $20 \mathrm{~g}$ soil $)$. Soil treated with $\mathrm{Fe}^{0}+\mathrm{Al}_{2}\left(\mathrm{SO}_{4}\right)_{3}$ was incubated for $2 \mathrm{~d}$; soil treated with $\mathrm{Fe}^{0}+\mathrm{CH}_{3} \mathrm{COOH}$ was incubated for $7 \mathrm{~d}$. Following incubation, the soil was extracted with $20 \mathrm{~mL}$ of $\mathrm{CH}_{3} \mathrm{CN}$ and analyzed by HPLC (procedure described in Soil Analysis, below).

\section{Field Experiment}

The stockpiled soil was moved with a front-end loader into seven windrows, five of which were used in the field experiment. Windrow dimensions were 3.35 to $3.65 \mathrm{~m}$ wide by 1.07 to $1.37 \mathrm{~m}$ high and 25.91 to $60.66 \mathrm{~m}$ in length. The soil in each windrow was mixed three times within $24 \mathrm{~h}$ by using a tractorpulled, high-speed soil mixing and fractionation implement (Frontier Industrial Corp., Salem, OR), sold under the trade name Microenfractionator (H\&H Eco Systems, North Bonneville, WA). This implement is similar in appearance to a conventional composter but differs in that its components have been augmented and redesigned to handle windrows containing $100 \%$ soil. This is facilitated by a John Deere (Moline, IL) $6068 \mathrm{~T}$ 170-horsepower diesel engine that propels a large $32-\mathrm{cm}$ (diam.) stainless steel rotating drum with 50 fan-knife blades (30.8-cm length). This implement also allows simultaneous injection of liquids (i.e., water and $\mathrm{CH}_{3} \mathrm{COOH}$ in this experiment) into the mixing tunnel via pressurized lines connected to a water tank, which is pulled along with the Microenfractionator (Fig. 1).

Following initial soil mixing, windrows were sampled approximately halfway up each side by using a hand-held soil probe $(2.5-\mathrm{cm}$ i.d., $53-\mathrm{cm}$ length). Three cores were taken every $6.1 \mathrm{~m}$ and composited. Samples were placed in an insulated cooler and transported to the laboratory. Each composite sample was analyzed for metolachlor and average concentrations per windrow were calculated.

Once the initial samples were obtained, five treatments were initiated, one per windrow. Treatments included: (i) control (no $\mathrm{Fe}^{0}$ ), (ii) $\mathrm{Fe}^{0}$-only, (iii) $\mathrm{Fe}^{0}+\mathrm{CH}_{3} \mathrm{COOH}$, (iv) $\mathrm{Fe}^{0}+$ $\mathrm{Al}_{2}\left(\mathrm{SO}_{4}\right)_{3}$, and $(\mathrm{v}) \mathrm{Fe}^{0}+\mathrm{CH}_{3} \mathrm{COOH}+\mathrm{Al}_{2}\left(\mathrm{SO}_{4}\right)_{3}$. Treatments were added as a percentage of the oven-dry soil mass, which was estimated by multiplying the volume of each windrow times a soil bulk density of $1.4 \mathrm{~g} \mathrm{~cm}^{-3}$. The $\mathrm{Fe}^{0}$ was added at $5 \%(\mathrm{w} / \mathrm{w}), \mathrm{CH}_{3} \mathrm{COOH}$ at $0.5 \%(\mathrm{v} / \mathrm{w})$, and commercial grade $\mathrm{Al}_{2}\left(\mathrm{SO}_{4}\right)_{3}$ at $2 \%(\mathrm{w} / \mathrm{w})$. Expressing these percentages in the

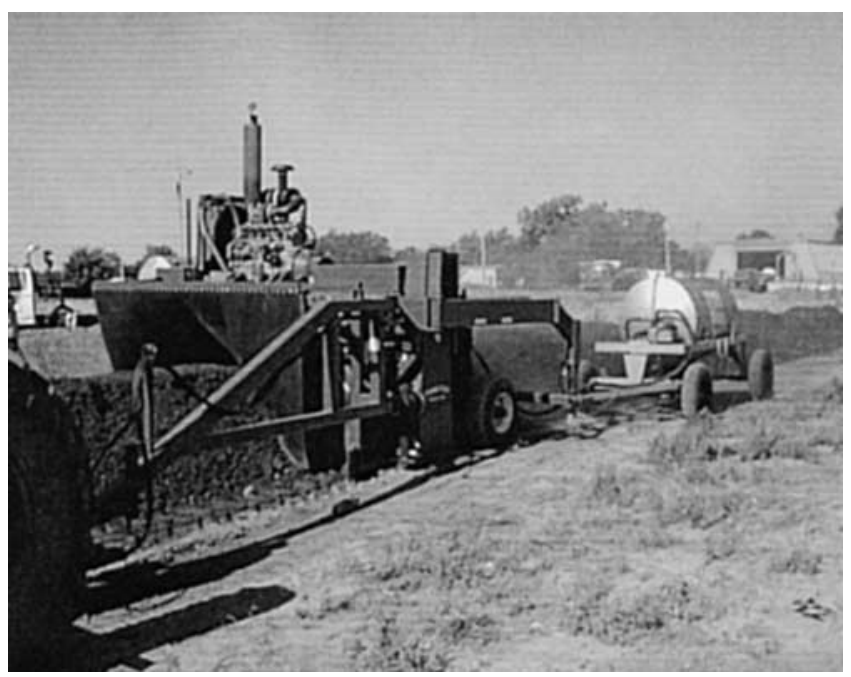

Fig. 1. Soil mixer and water tank being pulled through a soil windrow. 
Table 1. Soil physicochemical properties before $(t=0 \mathrm{~d})$ and after $(t=90 \mathrm{~d}$, mixed) treatment with zerovalent iron.

\begin{tabular}{|c|c|c|c|c|c|c|c|}
\hline Soil property & Unit & $\begin{array}{c}\text { Initial } \\
\text { concentration }\end{array}$ & Control & $\mathbf{F e}^{0}$ & $\begin{array}{c}\mathrm{Fe}^{0}+ \\
\mathrm{CH}_{3} \mathrm{COOH}\end{array}$ & $\begin{array}{c}\mathrm{Fe}^{0}+ \\
\mathrm{Al}_{2}\left(\mathrm{SO}_{4}\right)_{3}\end{array}$ & $\begin{array}{c}\mathrm{Fe}^{0}+ \\
\mathrm{CH}_{3} \mathrm{COOH}+ \\
\mathbf{A L}_{2}\left(\mathrm{SO}_{4}\right)_{3}\end{array}$ \\
\hline & & $t=\mathbf{0} \mathbf{d}$ & & 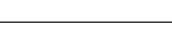 & $-t=90 \mathrm{~d}$ & & \\
\hline Phosphorus (weak Bray) & $\mathbf{m g ~ k g} \mathbf{~}^{-1}$ & $171(23) \dagger$ & $186(6)$ & 215 (14) & $182(3)$ & 98 (31) & $26(2)$ \\
\hline Nitrate $\mathbf{N}$ & mg kg $\mathbf{~ k g}^{-1}$ & $996(231)$ & $981(25)$ & 271 (14) & 85 (12) & $62(6)$ & $58(2)$ \\
\hline Ammoniacal $\mathbf{N}$ & $\mathbf{m g ~ k g ^ { - 1 }}$ & 5894 (902) & $5745(338)$ & $4075(954)$ & 3677 (256) & $4396(249)$ & 2901 (121) \\
\hline Total N & $\%$ & $1.11(0.13)$ & $1.17(0.02)$ & $0.97(0.04)$ & $0.82(0.03)$ & $0.85(0.06)$ & $0.55(0.01)$ \\
\hline Organic matter & $\%$ & $2.6(0.4)$ & $2.5(0.1)$ & $3.1(0.5)$ & $2.6(0.1)$ & $1.9(0.2)$ & $1.9(0.1)$ \\
\hline Cation exchange capacity & $\mathrm{cmol}_{\mathrm{c}} \mathbf{k g}^{-1}$ & 7.5 (1.1) & $12.1(0.3)$ & $11.5(0.8)$ & $12.4(0.0)$ & $20.4(0.8)$ & $25.0(0.7)$ \\
\hline Chloride & $\mathrm{mg} \mathrm{kg}^{-1}$ & $71(13)$ & $165(7)$ & $244(30)$ & $191(5)$ & $237(9)$ & $174(6)$ \\
\hline Sulfate & mg kg $\mathbf{k g}^{-1}$ & $622(21)$ & 586 (16) & 553 (57) & $464(7)$ & 8646 (256) & 8278 (65) \\
\hline Iron (DTPA $\doteqdot$ ) & mg kg $\mathbf{k g}^{-1}$ & $40(12)$ & 97 (17) & 368 (19) & 379 (2) & 325 (12) & 264 (1) \\
\hline Zinc (DTPA) & mg kg $\mathbf{k g}^{-1}$ & 66 (18) & $91(3)$ & $72(5)$ & $61(0)$ & 45 (2) & $58(0)$ \\
\hline Manganese (DTPA) & mg kg $\mathbf{~ k g}^{-1}$ & 53 (18) & 78 (4) & $82(3)$ & $90(5)$ & $105(4)$ & 105 (1) \\
\hline Copper (DTPA) & mg kg $\mathbf{k g}^{-1}$ & $3.0(1.2)$ & $5.0(1.9)$ & $29.2(2.0)$ & $40.5(1.4)$ & $27.0(1.2)$ & $28.4(0.4)$ \\
\hline Boron & mg kg $\mathbf{k g}^{-1}$ & $1.0(0.2)$ & $1.4(0.1)$ & $2.0(0.1)$ & $1.8(0.0)$ & $1.7(0.1)$ & $1.6(0.0)$ \\
\hline pH & & $6.6(0.1)$ & $6.4(0.1)$ & $7.6(0.1)$ & $8.1(0.0)$ & $7.1(0.1)$ & $7.5(0.0)$ \\
\hline Aluminum & $\mathbf{m g ~ k g ^ { - 1 }}$ & $2(1)$ & $1(1)$ & $4(2)$ & $3(2)$ & $2(1)$ & $2(1)$ \\
\hline Sand & $\%$ & 38 (7) & 43 (15) & $53(8)$ & $54(5)$ & $61(10)$ & $62(5)$ \\
\hline Silt & $\%$ & $33(6)$ & 35 (10) & 24 (9) & 37 (2) & 33 (8) & $33(5)$ \\
\hline Clay & $\%$ & $30(6)$ & $22(5)$ & 23 (1) & 9 (4) & $6(2)$ & 5 (1) \\
\hline
\end{tabular}

$\dagger$ Parenthetic values indicate sample standard deviation of means ( $n=5$ for initial, $n=3$ for treatments).

† DTPA = diethylenetriaminepentaacetic acid.

more conventional unit of mass of chemical added per cubic yard $\left(1 \mathrm{yd}^{3}=0.765 \mathrm{~m}^{3}\right)$ of soil $(1070 \mathrm{~kg}$ or $2360 \mathrm{lb}$, assuming a $1.4 \mathrm{~g} \mathrm{~cm}^{-3}$ bulk density), our treatment rates were equivalent to $53.5 \mathrm{~kg}(118 \mathrm{lb})$ of $\mathrm{Fe}^{0}, 21.4 \mathrm{~kg}(47.1 \mathrm{lb})$ of $\mathrm{Al}_{2}(\mathrm{SO} 4)_{3}$, and $5.4 \mathrm{~L}$ (1.42 gal) of acetic acid per $0.765 \mathrm{~m}^{3}\left(\mathrm{yd}^{3}\right)$ of contaminated soil.

The $\mathrm{Fe}^{0}$ was unannealed iron purchased from Peerless Metal Powders (Detroit, MI) in $22.7 \mathrm{~kg}$ unlined paper bags. This $\mathrm{Fe}^{0}$ had a specific surface area of $2.55 \mathrm{~m}^{2} \mathrm{~g}^{-1}$ (Micromeritics, Norcross, GA). Aluminum sulfate (commercial grade) was purchased in 22.7-kg bags from Van Waters \& Rogers (Omaha, NE). Glacial acetic acid was obtained in 208-L barrels from Celanese Chemicals (Dallas, TX), diluted with $\mathrm{H}_{2} \mathrm{O}$ and added during the mixing operations.

The required amounts of iron and $\mathrm{Al}_{2}\left(\mathrm{SO}_{4}\right)_{3}$ (in 22.7-kg unlined paper bags) were placed on top of the windrows and directly mixed in with the Microenfractionator a minimum of three times. Water and acetic acid were also added during the mixing process until the soil gravimetric water content was between 0.35 and $0.40 \mathrm{~kg} \mathrm{~kg}^{-1}$, which was determined at the field site by weight loss following repeated cycles of heating in a microwave oven. An added benefit of adding $\mathrm{H}_{2} \mathrm{O}$ during mixing was that it greatly reduced the amount of $\mathrm{Fe}^{0}$ dust released into the atmosphere during the first pass.

Once the desired soil water content was obtained, the windrows were covered with clear plastic that was held in place with wooden pallets. Windrows were sampled as described above at 1, 14, 28, 42, 60, 75, and $90 \mathrm{~d}$. After sampling at 14 , $28,42,60$, and $75 \mathrm{~d}$, additional water was applied to the top of the windrows (without mixing) to rewet the surface soil. Two sets of 90-d samples were taken, one before and one after mixing the windrows.

\section{Soil Analysis}

Soil samples obtained from the windrows were inventoried and stored at $4^{\circ} \mathrm{C}$. For each sample, we determined soil water content, $\mathrm{pH}$, and metolachlor concentration. Soil water content was determined on three 10 -g subsamples by determining weight loss after drying in a microwave oven. Soil $\mathrm{pH}$ was determined on 20-g soil samples (oven-dry basis) using a 1:1 soil to $\mathrm{H}_{2} \mathrm{O}$ ratio.

Metolachlor was extracted from 4.75 to 5.25 g soil (ovendry basis) in a $40-\mathrm{mL}$ Teflon centrifuge tube by adding $20 \mathrm{~mL}$
$\mathrm{CH}_{3} \mathrm{CN}$ and shaking overnight $(\geq 8 \mathrm{~h})$ on a reciprocating shaker at ambient temperature. The tubes were then centrifuged at $5000 \times g$ for $10 \mathrm{~min}$ and $1.5 \mathrm{~mL}$ was removed and microcentrifuged at $13000 \times g$ for an additional $10 \mathrm{~min}$. After centrifuging, $1 \mathrm{~mL}$ of supernatant was stored in a glass HPLC vial at $4^{\circ} \mathrm{C}$ until analysis.

Metolachlor and its dechlorinated product were measured by HPLC by injecting $20 \mu \mathrm{L}$ of the $\mathrm{CH}_{3} \mathrm{CN}$ extract into a 4.6by $250-\mathrm{mm}$ Keystone Betasil NA column (Keystone Scientific, Bellefonte, PA) connected to a Shimadzu (Kyoto, Japan) UV detector or photodiode array detector. The mobile phase was 50:50 acetonitrile and water at $1.0 \mathrm{~mL} \mathrm{~min}^{-1}$ with quantification at $220 \mathrm{~nm}$. Under these conditions, typical retention times were $12 \mathrm{~min}$ for metolachlor and $8 \mathrm{~min}$ for the dechlorinated metolachlor.

Standard soil nutrient and metal analyses (Table 1) were conducted by Midwest Analytical Laboratories (Omaha, NE) on initial $(t=0 \mathrm{~d})$ and $t=90 \mathrm{~d}$ (mixed) samples.

Statistical comparisons of metolachlor concentrations and soil $\mathrm{pH}$ among treatments were conducted using Tukey's multiple comparison procedure (Steel and Torrie, 1980) with a $5 \%$ probability of a Type I error $(\alpha=0.05)$.

\section{RESULTS AND DISCUSSION Laboratory Solution Experiments}

Adding $\mathrm{Al}_{2}\left(\mathrm{SO}_{4}\right)_{3}$ alone had no effect in altering metolachlor concentration. By contrast, when $\mathrm{Al}_{2}\left(\mathrm{SO}_{4}\right)_{3}$ was added with $\mathrm{Fe}^{0}$, first-order destruction rates were greatly increased (0.24 vs. $0.08 \mathrm{~h}^{-1}$; Fig. 2). Assuming removal of one mole of $\mathrm{Cl}^{-}$per mole of metolachlor, we recovered $>80 \%$ of the $\mathrm{Cl}^{-}$from the $\mathrm{Fe}^{0}$ treatments. A near stoichiometric recovery of $\mathrm{Cl}^{-}$coupled with the production of the dechlorinated product confirmed that dechlorination was the primary transformation occurring. Given that approximately $20 \%$ of the ${ }^{14} \mathrm{C}$ activity was lost within the first $2 \mathrm{~h}$ from solutions receiving $\mathrm{Fe}^{0}$, some adsorption of metolachlor and/or its dechlorinated product(s) onto the $\mathrm{Fe}^{0}$ occurred (Fig. 2). A decline in the dechlorinated product in the $\mathrm{Fe}^{0}+\mathrm{Al}_{2}\left(\mathrm{SO}_{4}\right)_{3}$ treatment after $12 \mathrm{~h}$, without further loss in solution ${ }^{14} \mathrm{C}$ activity, indi- 

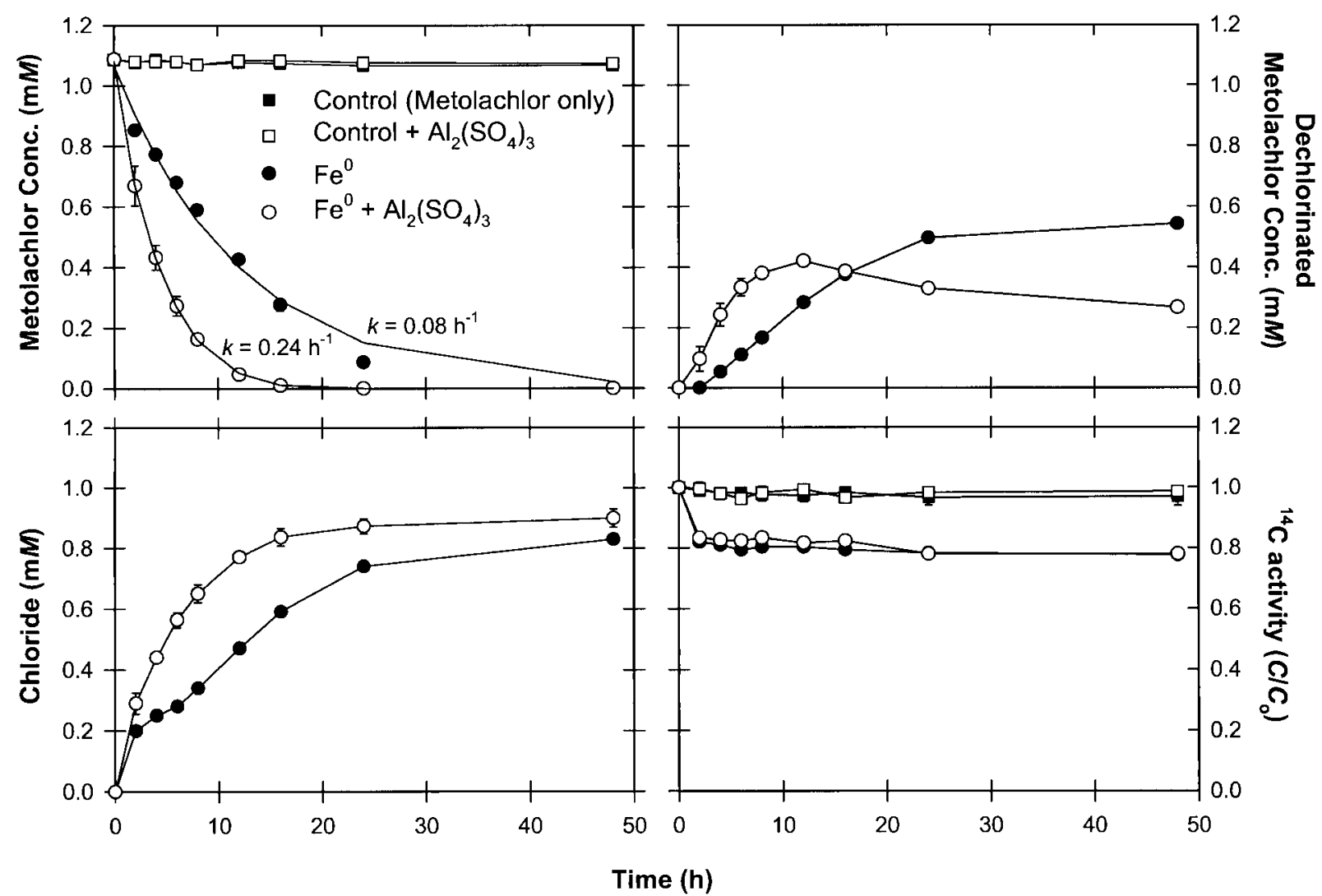

Fig. 2. Changes in metolachlor concentration, ${ }^{14} \mathrm{C}$ activity, and production of $\mathrm{Cl}^{-}$and dechlorinated metolachlor following addition of $\mathrm{Fe}^{0}$ or $\mathrm{Fe}^{0}+\mathrm{Al}_{2}\left(\mathrm{SO}_{4}\right)_{3}$ to aqueous solutions containing $1.09 \mathrm{mM}$ metolachlor spiked with ${ }^{14} \mathrm{C}$-metolachlor.

cates further transformation of the dechlorinated product. The companion experiment, which tested the effects of acetic acid on metolachlor transformation, produced similar results (Fig. 3), with acetic acid having an even more profound effect on the transformation rate $(k=$ $\left.0.39 \mathrm{~h}^{-1}\right)$. In this experiment, dechlorinated product was also produced (Fig. 3); $\mathrm{Cl}^{-}$could not be quantified due to interference from the acetic acid.

Iron metal added to aqueous solutions of metolachlor efficiently dechlorinated this chloroacetamide herbicide. The dechlorinated product [ $N$-(2-ethyl-6-methylphenyl)$\mathrm{N}$-(2-methoxy-1-methylethyl)acetamide] is formed when metolachlor accepts electrons released from oxidation of the $\mathrm{Fe}^{0}$ to $\mathrm{Fe}^{2+}$ and $\mathrm{Fe}^{3+}$. This reaction is promoted under acidic conditions and limited oxygen content. In summarizing the pathways of metolachlor degradation, Chesters et al. (1989) indicated that the same dechlorinated metolachlor product occurs naturally as a result of abiotic degradation in soil and sediment under anaerobic conditions.

Our results are consistent with previous reports of metolachlor dechlorination by iron metal in water (Eykholt and Davenport, 1998). Mass balance experiments using ${ }^{14} \mathrm{C}$-metolachlor, with measurement of the dechlorinated compound and recovery of $\mathrm{Cl}^{-}$released from metolachlor, indicated that the conversion is essentially complete, without the initial formation of other products.

Because dechlorination was the main destructive mechanism of the $\mathrm{Fe}^{0}$ treatment, we compared the biodegradability of metolachlor with the $\mathrm{Fe}^{0}$-treated metolachlor products in a mixed culture. The $\mathrm{Fe}^{0}$-treated products were five times more utilizable as a sole carbon source than metolachlor (cumulative ${ }^{14} \mathrm{CO}_{2}: 4.6$ vs. $0.89 \%$, Fig. 4 ), indicating that they are more biodegradable than the parent metolachlor. Singh et al. (1998b) similarly found in a $120-\mathrm{d}$ study that adding $\mathrm{Fe}^{0}$ to atrazine-contaminated soil increased cumulative mineralization from 4.1 to $11.2 \%$.

\section{Laboratory Soil Incubation Experiments}

Although batch solution experiments indicated that $\mathrm{Al}_{2}\left(\mathrm{SO}_{4}\right)_{3}$ and acetic acid had a complementary effect on $\mathrm{Fe}^{0}$-mediated metolachlor destruction, the optimum quantities required to treat the spill-site soil needed to be determined. Short-term soil incubations indicated that $2 \% \mathrm{Al}_{2}\left(\mathrm{SO}_{4}\right)_{3}(\mathrm{w} / \mathrm{w})$ and $0.5 \%$ acetic acid $(\mathrm{v} / \mathrm{w})$ effectively increased metolachlor destruction in static soil microcosms (Fig. 5). Because the greatest metolachlor destruction occurred within the first day of treatment (see below), these short-term incubations adequately determined the quantities of $\mathrm{Al}_{2}\left(\mathrm{SO}_{4}\right)_{3}$ and $\mathrm{CH}_{3} \mathrm{COOH}$ required for field-scale treatment.

\section{Metolachlor Spill Site}

The metolachlor concentration declined dramatically within $1 \mathrm{~d}$ after treating the soil windrows. Concentrations decreased from 1789 to $972 \mathrm{mg} \mathrm{kg}^{-1}$ (a $46 \%$ decline) for the $\mathrm{Fe}^{0}$-only treatment and from 1402 to $65 \mathrm{mg} \mathrm{kg}^{-1}$ (95\% decrease) for the $\mathrm{Fe}^{0}+\mathrm{CH}_{3} \mathrm{COOH}+\mathrm{Al}_{2}\left(\mathrm{SO}_{4}\right)_{3}$ 

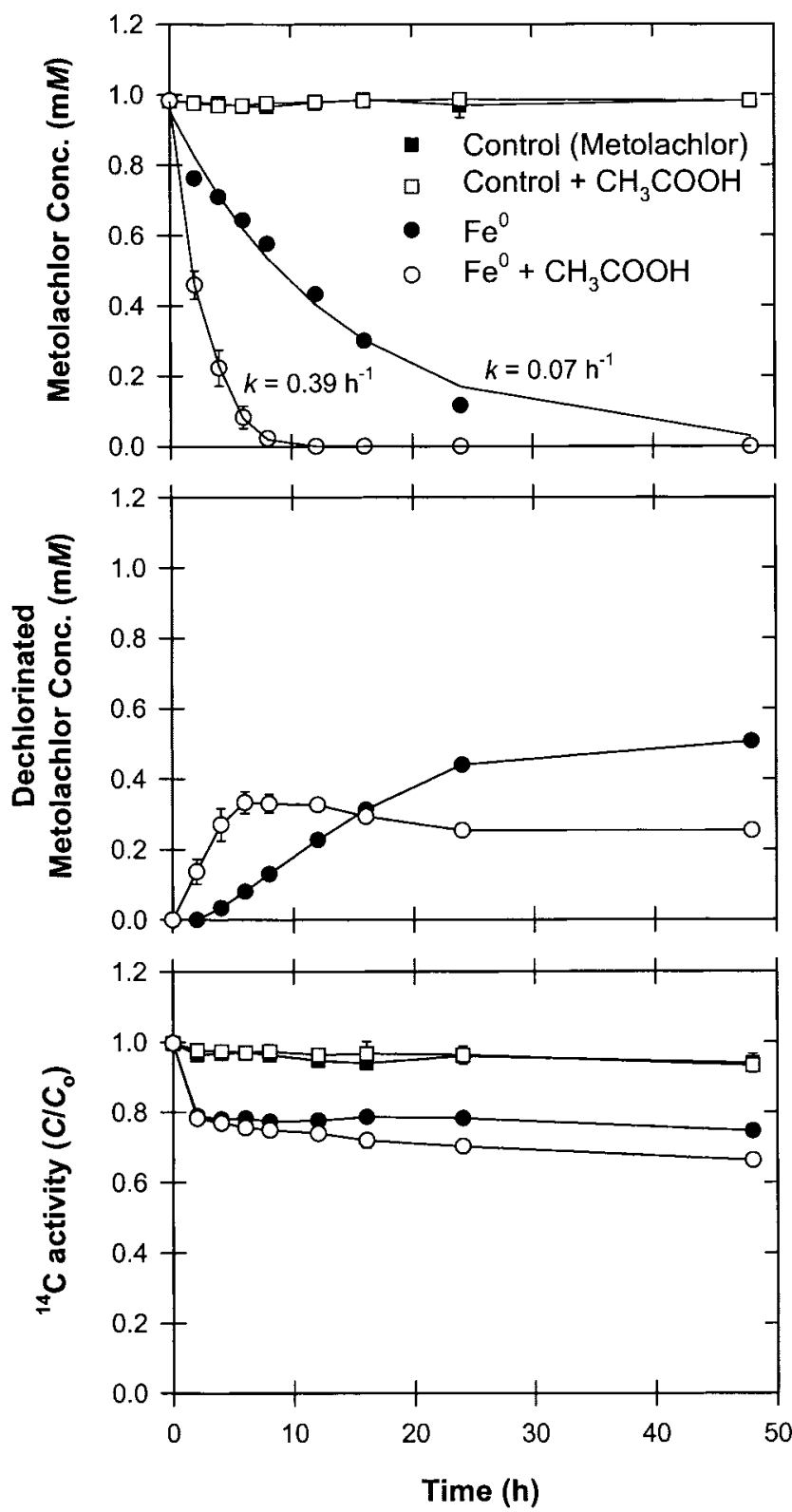

Fig. 3. Changes in metolachlor concentration, ${ }^{14} \mathrm{C}$ activity, and production of dechlorinated metolachlor following addition of $\mathrm{Fe}^{0}$ or $\mathrm{Fe}^{\mathbf{0}}+$ acetic acid to aqueous solutions containing $1.00 \mathrm{~m} M$ metolachlor spiked with ${ }^{14} \mathrm{C}$-metolachlor.

treatment (Table 2). The remaining samplings showed a general decrease in concentrations with time but variability in metolachlor concentrations within the windrows prevented us from observing continuous incremental decreases (Table 2). After mixing the windrows again at $t=90 \mathrm{~d}$, we observed the lowest concentrations of metolachlor obtained in this experiment, with final concentrations ranging between $504 \mathrm{mg} \mathrm{kg}^{-1}(72 \%$ decrease, $\mathrm{Fe}^{0}$ only) and $13 \mathrm{mg} \mathrm{kg}{ }^{-1}$ [99\% decrease, $\mathrm{Fe}^{0}+$ $\left.\mathrm{CH}_{3} \mathrm{COOH}+\mathrm{Al}_{2}\left(\mathrm{SO}_{4}\right)_{3}\right]$.

Notable observations from the field included dramatic changes in soil color following treatment. Within $1 \mathrm{~d}$, the surface of the soil had begun to brown from the oxidation of the iron. Immediately below the surface (ca. $1 \mathrm{~cm}$ ), the soil was gray to greenish gray, especially

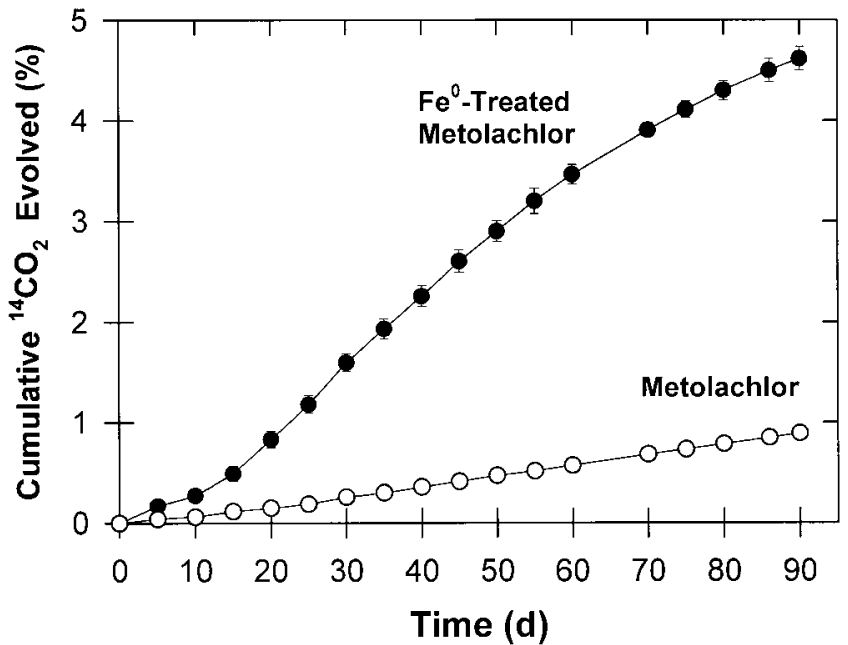

Fig. 4. Cumulative ${ }^{14} \mathrm{CO}_{2}$ evolved (percent of added ${ }^{14} \mathrm{C}$ ) from inoculated solution media containing ${ }^{14} \mathrm{C}$-labeled metolachlor or $\mathrm{Fe}^{\mathbf{0}}$ treated ${ }^{14} \mathrm{C}$-labeled metolachlor as the sole $\mathrm{C}$ source.

in windrows containing $\mathrm{Al}_{2}\left(\mathrm{SO}_{4}\right)_{3}$. This is probably due to the formation of green rust and reduced iron. Green rusts, often found as corrosion products of iron metal or as precipitates in anaerobic soils and sediments, are layered $\mathrm{Fe}(\mathrm{II})-\mathrm{Fe}(\mathrm{III})$ hydroxides with anionic interlayers $\left(\mathrm{CO}_{3}^{2-}, \mathrm{Cl}^{-}\right.$, and $\left.\mathrm{SO}_{4}^{2-}\right)$ (Erbs et al., 1999). Green rusts have been shown to play a role in the reduction of $\mathrm{NO}_{3}^{-}$(Hansen et al., 1996) and carbon tetrachloride (Erbs et al., 1999), which indicates that they may also promote the reduction of other nitrogenated and chlorinated compounds. In addition to their importance as reductants, green rusts can also be strong adsorbents due to the potential of their interlayers to sorb and exchange anions and polar uncharged molecules (Erbs et al., 1999).

With time, diffusion of oxygen into the windrow was inevitable and the brown oxidation layer at the surface gradually increased in size. Whereas the oxidation of green rust to goethite may also provide a source of electrons for reduction reactions, formation of a $\mathrm{Fe}$ (III) oxide layer passivates the iron surface. At the 14-d sampling, we took a vertical core in the $\mathrm{Fe}^{0}+\mathrm{CH}_{3} \mathrm{COOH}+$ $\mathrm{Al}_{2}\left(\mathrm{SO}_{4}\right)_{3}$-treated windrow and segmented it into three $10-\mathrm{cm}$ increments. The top (surface) segment, which was brown, had a metolachlor concentration of $34 \mathrm{mg} \mathrm{kg}^{-1}$ while the middle (brown-green) and bottom (green) sections $(10-20,20-30 \mathrm{~cm})$ had concentrations $\leq 9 \mathrm{mg} \mathrm{kg}^{-1}$. When the windrows were finally mixed at the end of the experiment $(t=90 \mathrm{~d})$, the center and bottom of the windrows still exhibited a green rust color. Based on these observations, it is likely that anoxic conditions were maintained in the center and bottom of the windrows and by mixing the windrows, we exposed soil that had greater rates of metolachlor destruction to areas where the windrows were routinely sampled. This probably explains why metolachlor concentrations were lower after the post-90 d mixing.

Comparisons among treatments at each sampling date revealed that the $\mathrm{Fe}^{0}$-only treatment significantly decreased metolachlor concentrations from the control (Ta- 
Table 2. Extractable metolachlor concentrations following treatment with zerovalent iron.

\begin{tabular}{|c|c|c|c|c|c|c|c|c|c|}
\hline Treatment & $\underset{\text { (mixed) }}{\text { Initial }} \dagger$ & 1 d & $14 \mathrm{~d}$ & $28 \mathrm{~d}$ & $42 \mathrm{~d}$ & $60 \mathrm{~d}$ & $75 \mathrm{~d}$ & $90 \mathrm{~d}$ & $\begin{array}{c}90 \mathrm{~d} \\
\text { (mixed) }\end{array}$ \\
\hline & & & & 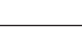 & $\mathbf{m g ~ k g}$ & & & & \\
\hline Control & 1813a & $1976 a$ & 1766a & 1638a & 1555a & 2035a & $1867 \mathbf{a}$ & $1826 a$ & 1522a \\
\hline $\mathbf{F e}^{0}$ & $1789 a$ & 972b & $769 b$ & $\mathbf{5 3 7 b}$ & $467 \mathrm{~b}$ & $676 b$ & $651 b$ & $486 b$ & $504 b$ \\
\hline $\mathrm{Fe}^{0}+\mathrm{CH}_{3} \mathrm{COOH}$ & $1740 a$ & $403 c$ & $220 \mathrm{c}$ & $162 \mathrm{c}$ & $178 c$ & $375 b c$ & $418 b c$ & $158 b c$ & $90 \mathrm{c}$ \\
\hline $\mathbf{F e}^{0}+\mathbf{A l}_{2}\left(\mathbf{S O}_{4}\right)_{3}$ & $1656 a$ & $105 c$ & $107 c$ & $104 c$ & $98 c$ & $53 c$ & $59 c$ & $108 c$ & $40 c$ \\
\hline $\mathrm{Fe}^{0}+\mathrm{CH}_{3} \mathrm{COOH}+\mathrm{Al}_{2}\left(\mathrm{SO}_{4}\right)_{3}$ & 1402a & $65 c$ & 41c & $34 c$ & $52 \mathrm{c}$ & $25 c$ & $34 c$ & $45 c$ & $13 c$ \\
\hline
\end{tabular}

$\dagger$ Mixed: windrows were mixed three times immediately before sampling.

$\$$ Values with same letter within columns are not significantly different $(\alpha=0.05)$.

ble 2). Adding $\mathrm{Al}_{2}\left(\mathrm{SO}_{4}\right)_{3}$, acetic acid, or both with $\mathrm{Fe}^{0}$ significantly increased metolachlor destruction. This was particularly apparent in treatments containing $\mathrm{Al}_{2}\left(\mathrm{SO}_{4}\right)_{3}$, which yielded the lowest metolachlor concentrations. Reasons for enhanced destruction by the addition of $\mathrm{Al}_{2}\left(\mathrm{SO}_{4}\right)_{3}$ and acetic acid are complex but can in part be attributed to alterations in soil solution $\mathrm{pH}$, redox potential, and soil solution composition during corrosion of the $\mathrm{Fe}^{0}$ surface. Decreasing $\mathrm{pH}$ will increase destruction rates by providing protons for reductive transformations and slow down $\mathrm{Fe}(\mathrm{II})$ oxidation and passivation of the iron surface. Although the $\mathrm{Al}_{2}\left(\mathrm{SO}_{4}\right)_{3}$ amendment significantly decreased soil $\mathrm{pH}$ in the windrows, the acetic acid treatment only slightly lowered the $\mathrm{pH}$ after application and residual effects were relatively shortlived (Table 3). After the first few samplings, $\mathrm{pH}$ tended to be higher in windrows receiving acetic acid than the comparable treatment $\left[\mathrm{Fe}^{0}\right.$ or $\mathrm{Fe}^{0}+\mathrm{Al}_{2}\left(\mathrm{SO}_{4}\right)_{3}$; Table 3].

The addition of acetic acid provided a readily utilizable carbon source that may have facilitated reductive transformations by producing an additional oxygen demand and source of electrons. It was also noted that individual grains of $\mathrm{Fe}^{0}$ in windrows treated with acetic acid were less visible and the soil as a whole appeared to have a more uniform iron coating. Formation of metal-organic complexes on surfaces will increase iron dissolution (Sidhu et al., 1981, Schwertmann et al., 1986). Therefore, the acetic acid probably facilitated the initial dissolution and subsequent distribution of dissolved iron throughout the soil. High concentrations of organic acids can also inhibit crystallization of iron oxides, favoring less well-structured matrices (such as ferrihydrite, green rust, and magnetite) with greater surface area (Heck and Mermut, 1999).

Aside from lowering the $\mathrm{pH}$, it is likely that the $\mathrm{Al}_{2}\left(\mathrm{SO}_{4}\right)_{3}$ played other roles in enhancing metolachlor destruction. An abundance of aluminum during $\mathrm{Fe}^{0}$ oxidation promotes its incorporation into the oxidized iron structure (Schwertmann and Cornell, 1991). This is important because $\mathrm{Al}^{3+}$ has a smaller ionic radius that disrupts crystallization and favors formation of ferrihydrite $\left(\mathrm{Fe}_{5} \mathrm{HO}_{8}\right)$ (Stucki et al., 1988). Ferrihydrite has a large surface area $\left(>200 \mathrm{~m}^{2} \mathrm{~g}^{-1}\right.$; Schwertmann and Cornell, 1991) and can serve as a reservoir for reduced iron (Baltpurvins et al., 1996). Klausen et al. (1995) demonstrated that $\mathrm{Fe}(\mathrm{II})$ bound to iron hydroxide surfaces or surface coatings plays an important role in reductive transformation of nitroaromatic compounds. Experiments conducted in our laboratory indicated that the presence of $\mathrm{Fe}(\mathrm{II}), \mathrm{Fe}(\mathrm{III})$, or $\mathrm{Al}(\mathrm{III})$ during $\mathrm{Fe}^{0}$ corrosion can facilitate metolachlor destruction in aqueous solution. In these experiments, $\mathrm{Al}(\mathrm{III})$ was readily sorbed by, and/or incorporated into, the oxidizing iron and this corresponded with a release of $\mathrm{Fe}(\mathrm{II})$ into solution. Therefore, an indirect effect of adding $\mathrm{Al}_{2}\left(\mathrm{SO}_{4}\right)_{3}$ was likely its influence on $\mathrm{Fe}(\mathrm{II})$ concentration in the soil solution during the corrosion of $\mathrm{Fe}^{0}$. Because sulfate was added as part of the $\mathrm{Al}_{2}\left(\mathrm{SO}_{4}\right)_{3}$, its presence must also be considered. Sulfate has been shown to sustain higher rates of iron corrosion (Reardon, 1995), apparently by dissolving the oxide film that coats the surface during oxidation (Gu et al., 1999). Under reducing conditions, sulfate also promotes formation of green rust II $\left[\mathrm{FeII}_{4} \mathrm{FeIII}_{2}(\mathrm{OH})_{12} \mathrm{SO}_{4} \cdot n \mathrm{H}_{2} \mathrm{O}\right]$ (Refait et al., 1999).

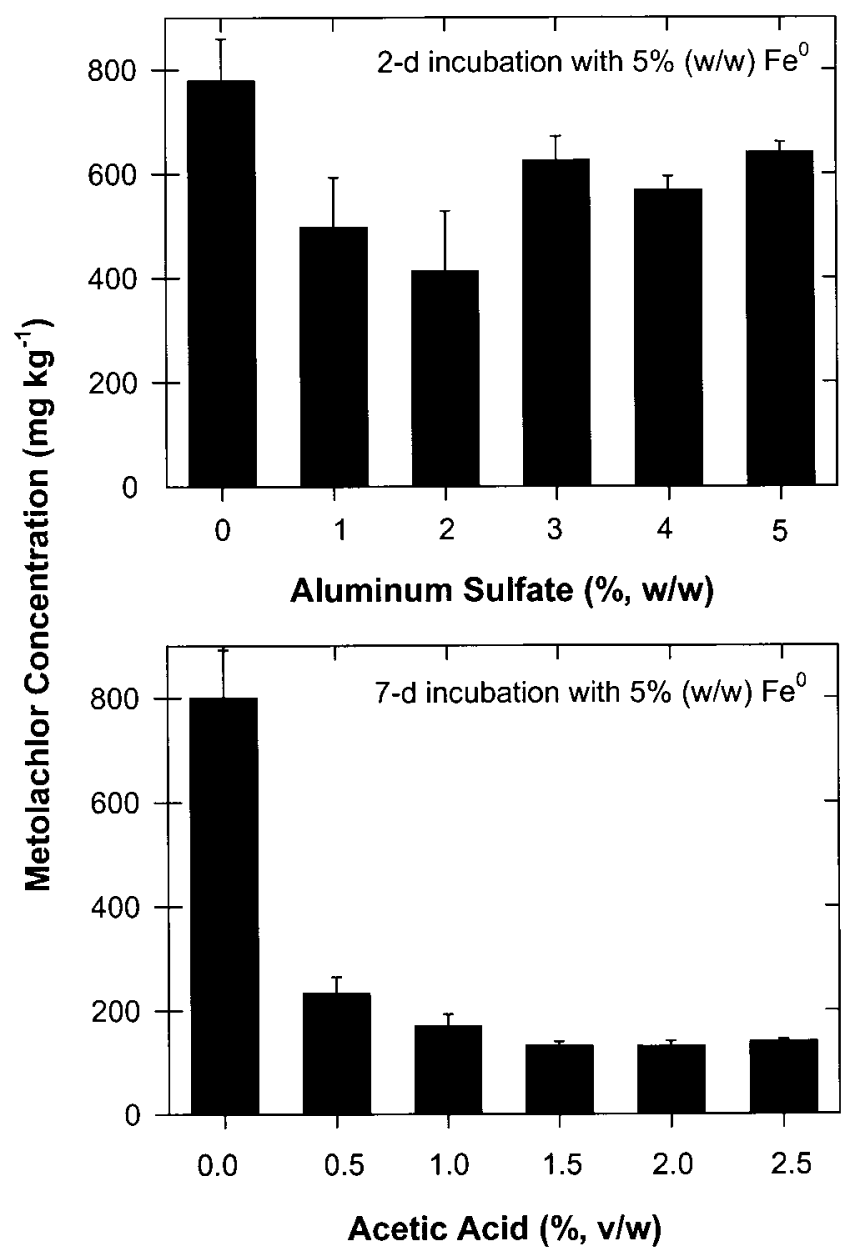

Fig. 5. Effects of $\mathrm{Al}_{2}\left(\mathrm{SO}_{4}\right)_{3}$ and acetic acid on metolachlor destruction in static soil microcosms treated with $5 \%(w / w) \mathbf{F e}^{0}$. 
Table 3. Soil pH following treatment with zerovalent iron.

\begin{tabular}{|c|c|c|c|c|c|c|c|c|c|}
\hline Treatment & $\underset{\text { (mixed) }}{\text { Initial }} \dagger$ & $1 \mathrm{~d}$ & $14 \mathrm{~d}$ & $28 \mathrm{~d}$ & $42 \mathrm{~d}$ & $60 \mathrm{~d}$ & $75 \mathrm{~d}$ & $90 \mathrm{~d}$ & $\begin{array}{c}90 \mathrm{~d} \\
\text { (mixed) }\end{array}$ \\
\hline Control & $6.45 b \div$ & $5.44 a$ & $5.99 \mathrm{a}$ & 6.03a & $6.16 a$ & 6.03a & $6.03 a$ & $6.13 a$ & $6.06 a$ \\
\hline $\mathbf{F e}^{0}$ & $6.55 b$ & 8.43d & $8.29 \mathrm{c}$ & $8.23 c$ & $8.17 \mathrm{c}$ & $7.87 \mathrm{c}$ & $7.84 b c$ & $7.74 b c$ & $8.22 d$ \\
\hline $\mathrm{Fe}^{0}+\mathrm{CH}_{3} \mathrm{COOH}$ & $6.43 b$ & $8.39 \mathrm{~d}$ & $8.36 \mathrm{c}$ & $8.59 c$ & $8.49 \mathrm{c}$ & $8.46 d$ & 8.38c & $8.16 c$ & $8.75 e$ \\
\hline $\mathbf{F E}^{0}+\mathbf{A L}_{2}\left(\mathbf{S O}_{4}\right)_{3}$ & $6.45 b$ & $7.01 c$ & $7.43 b$ & $7.39 \mathrm{~b}$ & $7.44 b$ & $7.16 b$ & 7.23b & $7.03 \mathrm{~b}$ & $7.22 \mathrm{~b}$ \\
\hline $\mathrm{Fe}^{0}+\mathrm{CH}_{3} \mathrm{COOH}+\mathrm{Al}_{2}\left(\mathrm{SO}_{4}\right)_{3}$ & $6.05 a$ & $6.37 \mathrm{~b}$ & $7.16 b$ & $7.27 b$ & $7.52 b$ & $7.46 \mathrm{bc}$ & 7.53b & $7.51 \mathrm{bc}$ & $7.50 \mathrm{c}$ \\
\hline
\end{tabular}

$\dagger$ Mixed: windrows were mixed three times immediately before sampling.

+ Values with same letter within columns are not significantly different $(\alpha=0.05)$.

\section{Changes in Soil Chemical Properties}

Initial analysis of the contaminated soil indicated that, in addition to metolachlor, this soil had very high concentrations of $\mathrm{NO}_{3}^{-}, \mathrm{NH}_{4}^{+}$, and $\mathrm{P}$ as well as diethylenetriaminepentaacetic acid (DTPA)-extractable metals (Zn, $\mathrm{Mn}, \mathrm{Fe}, \mathrm{Cu}$ ) (Table 1). Following $90 \mathrm{~d}$ of treatment, some notable increases and decreases in soil chemical properties were observed (Table 1). Phosphorus concentrations decreased in windrows receiving $\mathrm{Al}_{2}\left(\mathrm{SO}_{4}\right)_{3}$. Aluminum sulfate has been traditionally used to remove phosphate from wastewater streams by forming $\mathrm{AlPO}_{4}$ (Snoeyink and Jenkins, 1980). Hsu (1976) indicated the optimum $\mathrm{pH}$ for $\mathrm{P}$ removal by $\mathrm{Al}$ was 5.5 to 8.0, well within the range observed in the soil windrows (Table 3 ). Under acidic conditions $(\mathrm{pH}<6), \mathrm{AlPO}_{4}$ predominates, whereas at $\mathrm{pH} 6$ to 8 , an $\mathrm{Al}(\mathrm{OH})_{3}$ forms, which removes $\mathrm{P}$ from solution by sorption of inorganic phosphate and entrapment of organic particles containing $\mathrm{P}$ (Cooke et al., 1986).

Nitrate concentrations were also reduced substantially by all $\mathrm{Fe}^{0}$ treatments, corroborating previous research showing transformation of $\mathrm{NO}_{3}^{-}$to $\mathrm{NH}_{4}^{+}$upon addition of $\mathrm{Fe}^{0}$ (Cheng et al., 1997; Till et al., 1998). Other notable changes include an increase in $\mathrm{Cl}^{-}$, which is probably attributable to dechlorination of metolachlor, as well as increases in $\mathrm{SO}_{4}^{2-}$ for treatments receiving $\mathrm{Al}_{2}\left(\mathrm{SO}_{4}\right)_{3}$ (Table 1$)$. Although adding $\mathrm{Al}_{2}\left(\mathrm{SO}_{4}\right)_{3}$ with $\mathrm{Fe}^{0}$ increased metolachlor destruction, the high $\mathrm{SO}_{4}^{2-}$ concentrations observed after treatment are a potential concern, especially in terms of salinity and subsequent influence on plant growth. It is also noteworthy that despite the large additions of $\mathrm{Fe}^{0}$ and aluminum added to the soil, changes in DTPA-extractable iron increased only about eightfold (40 to ca. $300 \mathrm{mg} \mathrm{kg}^{-1}$ ) and no increases in extractable aluminum were observed (Table 1).

The ability of aluminum to complex with acidic functional groups of soil humus has been well documented (McBride, 1994). This property was manifested in the soil extracts from windrows receiving $\mathrm{Al}_{2}\left(\mathrm{SO}_{4}\right)_{3}$, which were transparent, whereas the others were dark brown. Binding of the dissolved organic fraction by the $\mathrm{Al}$ oxides probably explains the decreases in extractable organic matter observed in the $\mathrm{Al}_{2}\left(\mathrm{SO}_{4}\right)_{3}$ treatments and corresponding increases in cation exchange capacity (CEC) (Table 1).

\section{Treatment Costs}

In many U.S. states, pesticide-contaminated soils are usually handled in one of three ways: the contaminated soil is reapplied to farmland at label rates or the soil is excavated and shipped to a certified landfill or incinerated (Paulson, 1998). Land-spreading is relatively easy if access to appropriate acreages is obtained and pesticide concentrations are low, but problems arise when the soil contains more than one pesticide (limiting cropping options) or is grossly contaminated and requires dilution. Incineration or landfill options are often too costly and neither treat the soil on-site. Given the multitude of pesticide-contaminated sites on individual farms and cooperatives throughout the USA, additional treatment options are needed that can be readily implemented and are inexpensive for end-users.

An important factor in evaluating remediation technologies is cost. Although factoring in labor, capital outlays, and equipment depreciation is complicated, listing chemical expenditures per mass of soil treated is relatively straightforward. Given that the soil was treated with $5 \% \mathrm{Fe}^{0}(\mathrm{w} / \mathrm{w})$, and the unit cost of $\mathrm{Fe}^{0}$ (bagged and delivered) was $\$ 0.63$ per $\mathrm{kg}$, we calculated the cost of $\mathrm{Fe}^{0}$ at $\$ 44$ per $\mathrm{m}^{3}\left(\$ 34\right.$ per $\left.\mathrm{yd}^{3}\right)$. Using a similar approach for the $\mathrm{Al}_{2}\left(\mathrm{SO}_{4}\right)_{3}$ (unit cost: $\$ 0.37$ per kg) and acetic acid ( $\$ 0.90$ per L), the cost of these additions per cubic meter $\left(\mathrm{m}^{3}\right)$ of soil was $\$ 10.35\left(\$ 8\right.$ per $\left.\mathrm{yd}^{3}\right)$ for $\mathrm{Al}_{2}\left(\mathrm{SO}_{4}\right)_{3}$ and $\$ 6.33\left(\$ 4.84\right.$ per $\left.\mathrm{yd}^{3}\right)$ for acetic acid. Collectively, total chemical expenditures varied between $\$ 44$ and $\$ 61$ per $\mathrm{m}^{3}\left(\$ 34-\$ 47\right.$ per $\left.\mathrm{yd}^{3}\right)$. Additional costs were incurred for soil mixing, plastic sheeting, and analytical sampling. Unless personnel in charge of treating a contaminated site have access to their own mixing equipment, custom soil mixing would need to be factored into the overall costs. Soil mixing costs are often price-quoted on the volume of soil treated. H\&H EcoSystems, the vendor of the soil mixing implement we used, estimated custom mixing charges of approximately $\$ 33$ per $\mathrm{m}^{3}\left(\$ 25\right.$ per $\left.\mathrm{yd}^{3}\right)$ for the volume of soil treated (T. Horn, H\&H EcoSystems, personal communication, 2000). Therefore, chemical amendments plus mixing charges for treatment of the contaminated soil ranged between $\$ 77$ and $\$ 94$ per $\mathrm{m}^{3}\left(\$ 59-\$ 72\right.$ per $\left.\mathrm{yd}^{3}\right)$. This exceeds typical charges for land-spreading (ca. \$39 per $\mathrm{m}^{3}$ or $\$ 30$ per $\mathrm{yd}^{3}$ ) but is considerably less than what would be charged for removal and disposal by incineration (\$261-\$1961 per $\mathrm{m}^{3}, \$ 200-\$ 1500$ per yd $\mathrm{d}^{3}$; USEPA, 1990). The quote from the local incinerator in Nebraska was $\$ 790$ per $\mathrm{m}^{3}$ ( $\$ 604$ per $\left.\mathrm{yd}^{3}\right)$. Although land-spreading appears to be the most economical treatment currently available, this option may not be allowed for soils contaminated with the numerous pesticides that have been suspended or banned. Therefore, when land-spreading is not an option, results from our field trial support the 
use of $\mathrm{Fe}^{0}$ as a possible alternative for on-site treatment of pesticide-contaminated soil.

\section{ACKNOWLEDGMENTS}

We thank Compliance Advisory Services (Hastings, NE), Ag Valley Cooperative (Indianola, NE), and H\&H Eco Systems (North Bonneville, WA) for support and technical assistance. We also thank Syngenta (Greensboro, NC) for providing dechlorinated metolachlor and ${ }^{14} \mathrm{C}$-metolachlor. This research was supported in part by an Interdisciplinary Program grant from the UNL School of Natural Resource Sciences and Grants 95-32 (Great Plains-Rocky Mountain Hazardous Substance Research Center) and EPS-9255225 (NSF/EPSCoR). This paper is a contribution of the Agric. Res. Div. Projects NEB-40-002 and NEB-12-239, J. Ser. no. 13197. Mention of trade names is for the convenience of the reader and does not constitute endorsement or recommendation by the University of Nebraska.

\section{REFERENCES}

Agrawal, A., and P.G. Tratnyek. 1996. Reduction of nitro aromatic compounds by zero-valent iron metal. Environ. Sci. Technol. 30: 153-160.

Baltpurvins, K.A., R.C. Burns, G.A. Lawrence, and A.D. Stuart. 1996. Effect of $\mathrm{pH}$ and anion type on the aging of freshly precipitated iron (III) hydroxide sludges. Environ. Sci. Technol. 30:939-944.

Butler, L.C., D.C. Staiff, G.W. Sovocool, and J.E. Davis. 1981. Field disposal of methyl parathion using acidified powdered zinc. J. Environ. Sci. Health B16:49-58.

Cheng, F., R. Muftikian, Q. Fernando, and N. Korte. 1997. Reduction of nitrate to ammonia by zero-valent iron. Chemosphere 35:26892695.

Chesters, G., G.V. Simsiman, J. Levy, B.J. Alhajjar, R.N. Fathulla, and J.M. Harkin. 1989. Environmental fate of alachlor and metolachlor. Rev. Environ. Contam. Toxicol. 110:11-74.

Cooke, G.D., E.B. Welch, S.A. Peterson, and P.R. Newroth. 1986. Lake and reservoir restoration. Butterworths, Ann Arbor Science Book, Boston.

Cutshall, E.R., G. Felling, S.D. Scott, and G.S. Tittle. 1993. Method and apparatus for treating PCB-containing soil. U.S. Patent 5197 823. Date issued: 30 March

Erbs, M., H.C.B. Hansen, and C.E. Olsen. 1999. Reductive dechlorination of carbon tetrachloride using iron (II) iron(III) hydroxide sulfate (green rust). Environ. Sci. Technol. 33:307-311.

Eykholt, G.R., and D.T. Davenport. 1998. Dechlorination of the chloroacetanilide herbicides alachlor and metolachlor by iron metal. Environ. Sci. Technol. 32:1482-1487.

Fathepure, B.Z., and J.M. Tiedje. 1999. Anaerobic bioremediation: Microbiology principles, and applications. p. 339-396. In D.C. Adriano, J.-M. Bollag, W.T. Frankenberger, and R.C. Sims (ed.) Bioremediation of contaminated soils. Agron. Monogr. 37. ASA, Madison, WI.

Gillham, R.W., and S.F. O'Hannesin. 1994. Enhanced degradation of halogenated aliphatics by zero-valent iron. Ground Water 32:958-967.

Gu, B., T.J. Phelps, L. Liang, M.J. Dickey, Y. Roh, B.L. Kinsall, A.V. Palumbo, and G.K. Jacobs. 1999. Biogeochemical dynamics in zerovalent iron columns: Implications for permeable reactive barriers. Environ. Sci. Technol. 33:2170-2179.

Hansen, H.C.R., C.B. Koch, H. Nancke-Krogh, O.K. Borggaard, and
J. Sørensen. 1996. Abiotic nitrate reduction to ammonium: Key role of green rust. Environ. Sci. Technol. 30:2053-2056.

Heck, R.J., and A.R. Mermut. 1999. Mechanism and rates of iron dissolution from Brazilian plinthustalfs by dilute hydrochloric and ascorbic acids. Soil Sci. 164:242-251.

Hsu, P.H. 1976. Comparison of iron(III) and aluminum in precipitation of phosphate from solutions. Water Res. 10:903-907.

Hundal, L.S., J. Singh, E.L. Bier, P.J. Shea, S.D. Comfort, and W.L. Powers. 1997. Removal of TNT and RDX from water and soil using iron metal. Environ. Pollut. 97:55-64.

Klausen, J., S.P. Trober, S.B. Haderlein, and R.P. Schwarzenbach 1995. Reduction of substituted nitrobenzenes by $\mathrm{Fe}(\mathrm{II})$ in aqueous mineral suspensions. Environ. Sci. Technol. 29:2396-2404.

McBride, M.B. 1994. Environmental chemistry of soils. Oxford Univ. Press, New York.

Paulson, D. 1998. Industrial aspects of remediation-Environmental safety. p. 21-33. In P.C. Kearney and T. Roberts (ed.) Pesticide remediation in soils and water. John Wiley \& Sons, New York.

Reardon, E.J. 1995. Anaerobic corrosion of granular iron: Measurement and interpretation of hydrogen evolution rates. Environ. Sci. Technol. 29:2936-2945.

Refait, Ph., C. Bon, L. Simon, G. Bourrie, F. Troland, J. Bessiere, and J.-M.R. Genin. 1999. Chemical composition and Gibbs standard free energy of formation of $\mathrm{Fe}$ (II)-Fe(III) hydroxsulfate green rust and Fe(II) hydroxide. Clay Miner. 34:499-510.

Schwertmann, U., and R.M. Cornell. 1991. Iron oxides in the laboratory. VCH Publ., New York.

Schwertmann, U., H. Kodama, and W.R. Fischer. 1986. Mutual interactions between organics and iron oxides. p. 223-250. In P.M. Huang and M. Schnitzer (ed.) Interactions of soil minerals with natural organic and microbes. SSSA Spec. Publ. 17. SSSA, Madison, WI.

Sidhu, P.S., R.J. Gilkes, R.M. Cornell, A.M. Posner, and J.P. Quirk. 1981. Dissolution of iron oxides and oxyhydroxides in hydrochloric acid and perchloric acids. Clays Clay Miner. 29:269-276.

Singh, J., S.D. Comfort, and P.J. Shea. 1998a. Remediating RDX-contaminated water and soil using zero-valent iron. J. Environ. Qual. 27:1240-1245.

Singh, J., S.D. Comfort, and P.J. Shea. 1999. Iron-mediated remediation of RDX-contaminated water and soil under controlled Eh-pH. Environ. Sci. Technol. 33:1488-1494.

Singh, J., P.J. Shea, L.S. Hundal, S.D. Comfort, T.C. Zhang, and D.S. Hage. 1998b. Iron-enhanced remediation of water and soil containing atrazine. Weed Sci. 46:381-388.

Snoeyink, V.L., and D. Jenkins. 1980. Water chemistry. John Wiley \& Sons, New York.

Staiff, D.C., L.C. Butler, and J.E. Davis. 1977. Field disposal of DDT: Effectiveness of acidified powdered zinc on reduction of DDT in soil. J. Environ. Sci. Health B12:1-13.

Steel, R.G.D., and J.H. Torrie. 1980. Principles and procedures of statistics. A biometrical approach. 2nd ed. McGraw-Hill Book Co., New York.

Stucki, J.W., B.A. Goodman, and U. Schwertmann. 1988. Iron in soils and clay minerals. D. Riedel Publ. Co., Boston.

Suflita, J.M., A. Horowitz, D.R. Shelton, and J.M. Tiedje. 1982. Dehalogenation: A novel pathway for the anaerobic biodegradation of haloaromatic compounds. Science 218:1115-1117.

Till, B.A., L.J. Weathers, and P.J. Alvarez. 1998. Fe(0)-supported autotrophic denitrification. Environ. Sci. Technol. 32:634-639.

USEPA. 1990. Engineering bulletin: Mobile/transportable incineration treatment. EPA/540/2-90/014. Office of Emergency and Remedial Response, Washington, DC, Office of Res. and Development, Cincinnati, $\mathrm{OH}$.

Weast, R.C. 1978. Handbook of chemistry and physics. 58th ed. CRC Press, West Palm Beach, FL. 